\title{
Methodological Foundations Assessment of Security Control of the Information And Telecommunications Network Register of Municipal Property
}

\author{
Popadyuk, N.K. ${ }^{1}$, Rojdestvenskaya, I.A. ${ }^{2}$, Gladyshev, A.G. ${ }^{3}$, Izotova, G.S. ${ }^{4}$, d Danilkevich, M.A ${ }^{5}$ \\ ${ }^{1}$ Federal state educational budgetary institution of higher education"Financial University under the Government \\ of the Russian Federation"125993, Moscow \\ ${ }^{2}$ Federal state educational budgetary institution of higher education”Financial University under the Government \\ of the Russian Federation"125993, Moscow \\ ${ }^{3}$ Federal state educational budgetary institution of higher education"Financial University under the Government \\ of the Russian Federation"125993, Moscow \\ ${ }^{4}$ Federal state educational budgetary institution of higher education"Financial University under the Government \\ of the Russian Federation"125993, Moscow \\ ${ }^{5}$ Federal state educational budgetary institution of higher education"Financial University under the Government \\ of the Russian Federation"125993, Moscow
}

\begin{abstract}
During the anti-terrorist operation there is a search for appropriate ways to create and improve a scientifically sound, economically feasible system of protection of information resources in information and telecommunications networks for special purposes. This work is devoted to the consideration of methodological bases for assessing the security control of information and telecommunication networks for special purposes. The aim of the article is to increase the security of information and telecommunication networks for special purposes by using as a basic method of analysis of hierarchies and the apparatus of neural fuzzy networks to assess the security of networks of this class. The generalized characteristic of the basic groups of methods of an estimation of control of protection of information and telecommunication networks of this class is resulted. At p stopping the task of assessing the security control of information and telecommunications networks for special purposes as a system of information resources, its following indicators are determined: the priority of protected information, the probability of hacking, the cost of the protection system, system performance. To set the proposed parameters for assessing the security of the system can be used research methods that include theories: graphs, decision support systems, fuzzy sets, neural networks, methods of multicriteria optimization, expert methods. It is proposed to use as a basic method of analysis of hierarchies and apparatus of neural-fuzzy networks for further development of the method of assessment of security control of information and telecommunication network of special purpose.
\end{abstract}

Key words: Multicriterial, telecommunication, neural network, security control.

\section{INTRODUCTION}

When setting objectives assess control of security information - telecommunication networks Special purpose as system information resources $\mathrm{S}$ should define its following indicators: priority information, which is protected, the likelihood of cracking, the cost of the system of protection, performance systems [3]. For the task proposed parameter estimation security system may use methods of study, which include theory: graphs, systems support decision- making, fuzzy sets, neural networks, methods of multi-objective optimization, expert methods [11-14].

Abstract oriented graph is the basis for planning actions of man - operator, changing the order of the sequence of his actions, conduct operations. Setting tasks of network planning starts with identifying nodal points (events) operations, which determine the beginning and end of the core of the stages, after which the determined measures, that lead to the execution of each event and accompanied by spending time and resources. Then events and relevant they work arranged in some logical sequence, which is represented graphically in the form of a network graph, which reflects all the ways achieve the ultimate goal of the operation. Building a network graph starts with determining the list of events and their application in the graph according to rank [1-3]. Rank event determined its serial nom erom in the overall sequence of events, as, for example, the original event has zero rank, which follows on it - the first and so on. Then, on the count put the work in the form of lines, that of ' connects initial and subsequent events. In the general case, the network graph (Fig. 1) presents a graph, the nodes is a $\mathrm{x}$ - event and focused $\operatorname{arc} \mathrm{A} \mathrm{xy}$ - work, $\mathrm{x}>$ $y$. With this in column either - which curve reflects only one job, and in case of occurrence of a situation, when two works are those most outgoing and incoming units (events) introduced an additional fictitious work, not surf commitments of expenditure of time and other resources [4-10]. 


\section{MATERIALS AND METHODS}

One of the possible sequences of events and operations from the original event to finish her is a way to network graph, a path, which is the maximum time performance of each of the input in his work and the total time of execution of the whole operation is a critical way. The use of different methods for assessing the security of the system determines the choice of the basic method. With the above methods most appropriate is the use of expert methods, so that it solved with their performance in the evaluation of partial performance security information - telecommunication network special purpose. There are the following types of the most common expert methods: the method of ranking, the method of pairwise comparisons, the method of Delphi, the method of setting weights, and so on [11-14].

The method of ranking appears in general as well, as an expert or several expert $\mathrm{s}$ base attributes about ' facility or alternatives in order preferences or in the most rational form. For example, the first about ' object is the most important sign, the second is next in importance and so further. In the case when data from experts are collected, the received estimates are processed.

To determine the concurrence of experts' opinions, the concordance coefficient is calculated. Quantitative value ratio is in the range from 0 to 1 , with this zero means complete opposite opinions of experts, and the unit - complete coincidence ranked. When sufficiently large for about objects or alternatives used method of pairwise comparisons. The method of analysis of hierarchies, which belongs to the class of methods of pairwise comparisons, has become quite widely used [15]. Quite difficult problem can be presented in a three-level hierarchy goal - Criteria - alternatives), and each of the elements of the hierarchy when necessary, can be submitted, in its turn, in a three-level hierarchy and so more. At the time of application of the method of analysis of hierarchies established priority criteria and evaluated each of the alternatives for the relevant criteria. In this method, the elements of one level of the hierarchy pairs in relation to them - its weight on a common characteristic for them [16]. The system of paired data leads to results, which may be represented in the form of a symmetric matrix. An element of the matrix b $(\mathrm{k}, \mathrm{l})$ is the intensity of display element hierarchy $\mathrm{k}$ on the element hierarchy 1 , which is estimated on the scale of intensity from 1 to 9 , as proposed by the author of the method, which estimates are offensive meaning: 1 - equal importance; 3 - moderate advantage of one over the other ; 5 - significant advantage of one over the other ; 7 - a significant advantage of one over the other ; 9 - a very strong advantage of one over the other; 2, 4, 6, 8 - the corresponding intermediate values. If when comparing one criterion $\mathrm{k}$ with another 1 we get $\mathrm{b}(\mathrm{k}, \mathrm{l})=$ $\mathrm{c}$, then when comparing the second factor with the first we get $\mathrm{b}(\mathrm{k}, \mathrm{l})=1 / \mathrm{c}$. Relative strength, value or likelihood of each individual about ' object in the hierarchy is determined by assessment appropriate to it an element of their own vector of priorities, which normalized to unity. The procedure for determining its own vector matrix undergoes convergence by means of calculating geometric average. Local priorities multiplied on priority appropriate criteria to a higher level and to each factor according to the criteria, on which impact element [17-20].

The formal apparatus for processing expert information is a mathematical apparatus of fuzzy sets, which allows to form decision- making rules for assessing the security control of network nodes. Formalize relevant information possible, using linguistic variables "priority information", "probability of cracking", "value system protection", "performance system". Linguistic variables "priority info", "probability of cracking", "value system protection" are input variables, linguistic variable "performance system"- the original variable. Constructed functions belonging to each linguistic variable, formed fuzzy base of knowledge on the basis of production rules, which is caused by the necessity of keeping the real scale of time and convenience submitting information about the procedures and conditions for their implementation. So the decision problem determination procedure control security node network based on the $\mathrm{u}$ or apparatus theory of fuzzy sets [12]. As a further result of evaluation control of security appropriate network can be used with the application of the theory of neural networks. The essence of the neural network is in the approximation of functions of many variables by using linear operations. At the entrance to the network filed a set of values and simultaneously given an appropriate set of initial values (Fig. 2) [11]. Neural networks and fuzzy logic are universal approximations complex (nonlinear) functional dependence in many intellectual problems of cybernetics. The main feature of neural networks is their ability to study, which is realized by using specially developed algorithms. No a priori information about the structure of the required functional dependence is required for neural network training. All you need is an instructive sample in the form of experimental pairs "inputs - outputs". The advantage of fuzzy logic is the possibility of using expert knowledge of the structure about ' facility in the form of linguistic expressions: if the "inputs", then "exit". However, the device of fuzzy logic does not contain mechanisms for training, because the results of fuzzy logic conclusion strongly dependent on the type of functions belonging, which formalized vague terms.

Reference fuzzy logic with neural networks neural network has two major intellectual properties: IE the use of knowledge in natural language, and the ability to study in real scale of time [11].

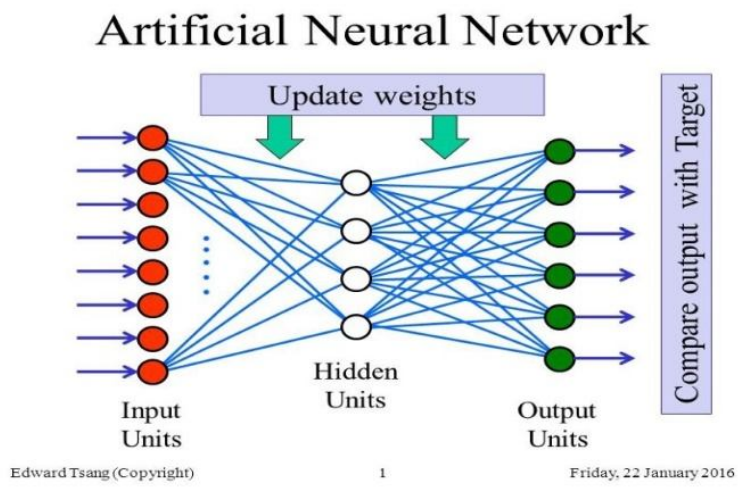

Figure 1: Neural network model for security control 
Popadyuk, N.K et al., International Journal of Advanced Trends in Computer Science and Engineering, 9(4), July - August 2020,6598 - 6602

Figure 1 shows us neural network model for security control in network.

Analysis of the literature [14] showed, that all the numerous methods of solution ' Liabilities multi tasks may be reduced to three groups of methods: the method of the main index, the method resulting index, lexicographic method ( a method of successive concessions ) [21-24].

Method main index based on the transfer of indicators of quality, in addition to which - ever chief, in the category of restrictions such as equalities or inequalities. Assign the number $\mathrm{qS} \leq 1$ to the main indicator. Then the problem is reduced to a single-criterion problem of choosing a system $S$ $\mathrm{M} \leq \mathrm{S}$, which has a minimum value of $\mathrm{q} 1$ (S) in the presence of constraints such as equalities and inequalities, ie has the formmin $\mathrm{q} 1 \leq \mathrm{S}$; under constraints q $1(\mathrm{~S})=\mathrm{q} \mathrm{j} 0 ; \mathrm{j}=2, \ldots, \mathrm{v}$; $\mathrm{q} \leq \mathrm{w} ; \mathrm{SM} \leq \mathrm{S}$

$(\mathrm{S}) \leq \mathrm{q} w 0 ; \mathrm{w}=\mathrm{v}+1, \ldots, \mathrm{d} ; \mathrm{qh}(\mathrm{S}) \geq \mathrm{qh} 0 ; \mathrm{h}=\mathrm{d}+1, \ldots, \mathrm{m}$.

In most cases there is no sufficient reason for that, to figure out what - ever specified a figure chief, and all others - minor. At the same time, for quality indicators $\mathrm{q} 2 \mathrm{~S}, \ldots, \mathrm{qm}$, which are translated into the category of restrictions, it is difficult to establish their allowable values. The method of the resulting quality indicator is based on the formation of a generalized indicator by intuitive assessments of the impact of partial quality indicators q, ..., q $1 \mathrm{~m}$ on the resulting quality of the system's performance of its functions. Estimates of the impact given to a group of specialists - experts, who have experience in developing such systems [25].

The greatest use of the resulting indicators of quality were additive, multiplicative and minimax rates [26].

For EID target function when designing the subsystem control security information corresponding system may use a number of indicators by using the method of task weighting coefficients . For example, for the method of weighted sum of ratings criteria usefulness $U$ multi against ' facility is set regardless [14]

From the set of options for building a subsystem for information protection of this system, you must choose a rational option. The use of the additive and multiplicative parameters, you can make a conclusion on the fact, that the first of them is based on the principle of fair absolute concessions for certain indicators, and the second - on the principle of fair relative concessions, and minimax rate provides the best ( highest ) value of the worst ( lowest ) with partial quality indicators.

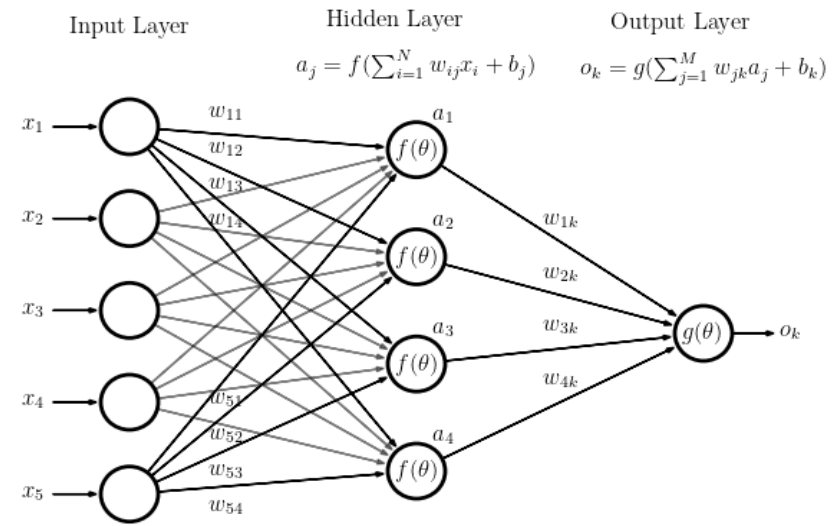

Figure 2:Neural network with coefficients
Figure 2 shows us neural network with weight coefficients. When using the lexicographic method to determine the objective function in the design of the information security control subsystem, the quality indicators $q \mathrm{j}$ are ordered by importance q $1(\mathrm{~S})>\mathrm{q} 2(\mathrm{~S})>\ldots>\mathrm{q} \mathrm{m}(\mathrm{S})$. The essence of the lexicographic method is to first select the set of alternatives with the best score on the most important indicator. If the alternative is the only one, then it is considered the best ; if they are several, then with these kind those, who have a better estimate for the second index and so on [27-31]. To expand the set of considered alternatives and improve the quality of decisions on aggregate indicators can be assigned assignment, in the framework of which alternatives are considered equivalent . The principal feature of the considered problem of choosing rational options subsystem protection of information is mainly qualitative in nature indicators, which are treated as claims, which are set to the subsystem defense information. In -called ' connection with this considered methods of multi-objective optimization should be formulated in a fuzzy statement. As a classical way and a fuzzy setting selection method solutions multi task defined so, in what form provided expert information about preference flashy or their importance. In the future, when the values of $\mathrm{q} 1 ; \mathrm{q} 2 ; \mathrm{q} 3 ; \mathrm{q} 4$ consider the following quality indicators of the protection subsystem: q 1 - priority information; q 2 - the probability of breaking the subsystem ; q 3 - the cost of the subsystem ; q 4 subsystem performance .

\section{CONCLUSION}

So this generalized description of the main groups of methods of evaluation control of security information telecommunication networks, special purpose. Quality solution of the problem is impossible without the use of support adoption of the decision. On the basis of the conducted analysis to quality basic invited to use the method of analysis of hierarchies and apparatus neural - fuzzy network by defining tasks assessment control of security relevant systems. The next stage of the study will be the development of a method for assessing the theft of information and telecommunications networks for special purposes.

\section{REFERENCES}

1. The Constitution of the Russian Federation (adopted by popular vote 12.12.1993) (as amended, amended Laws of the Russian Federation on amendments to the Constitution of the Russian Federation from 30.12.2008 № 6-FKZ, from 30.12.2008 № 7-FKZ, from 05.02.2014 No. 2-FKZ, from 21.07.2014 No. 11-FCL) [Electronic resource]:

http://www.consultant.ru/document/cons_doc_LAW_28 $399 /$.

2. The civil code of the Russian Federation. Article 215 "the right of municipal property" [electronic resource":

http://www.consultant.ru/document/cons_doc_LAW_51 42/914c87af629ff4807a2871517c90cbc083d24ae3/. 
3. The civil code of the Russian Federation. Article 294 "the right of economic management"[electronic resource":

http://www.consultant.ru/document/cons_doc_LAW_51 42/00cc95b44fccac543e2cbde81f51a56e1032bf60/.

4. The civil code of the Russian Federation. Article 296 "the right of operational management" [electronic resource":

http://www.consultant.ru/document/cons_doc_LAW_51 42/e842f7d159aa68f9ccac4fbdedf7f01dad5fbf04/.

5. The civil code of the Russian Federation. Article 125"Procedure for participation of the Russian Federation, subjects of the Russian Federation, municipalities in relations regulated by civil legislation"[Electronic resource]:

http://www.consultant.ru/document/cons_doc_LAW_51 42/53408843126f2204aba45a6195da864ff0319198/.

6. Resolution of the Supreme Soviet of the Russian Federation of 27.12.1991No. 3020-1 (ed. from 24.12.1993)" on the division of state property in the Russian Federation into Federal property, state property of republics within the Russian Federation, territories, regions, Autonomous regions, Autonomous districts, cities of Moscow and Saint Petersburg and municipal property"[Electronic resource]:

http://www.consultant.ru/document/cons_doc_LAW_20 $8 /$

7. Decree of the Government of the Russian Federation of December 8, 2011 No. 2227-R"'on the strategy of innovative development of the Russian Federation for the period up to 2020"[Electronic resource]: https://www.garant.ru/products/ipo/prime/doc/70006124 /\#72.

8. Federal law No. 154-FZ of August 28, 1995'On General principles of local self-government organization in the Russian Federation"(with amendments and additions). Chapter V. Financial and economic basis of local self-government. Article 29 [electronic resource]: https://base.garant.ru/10104758/7a69fb6632f5876efd31 60114758a106/.

9. Federal law of $\mathbf{0 6 . 1 0 . 2 0 0 3} \mathrm{N}$ 131-FZ (Ed. from 03.07.2018)"On General principles of the organization of local self-government in the Russian Federation"

10. Artemyev, A. A. Significance of territorial interest in property management in the region and municipality // Theory and practice of social development. - 2014. - № 1. - P. 116-118.

11. Egorova, I. S., Sokolova T. A. on the effectiveness of municipal property management. - Pp. 138-143.

12. Erofeev, I. S. Problems of effective management of municipal property // Domestic jurisprudence. - 2018. Pp. 42-43.

13. Eroshkin, A. K. System of municipal property management in the Russian Federation / / Young scientist. - 2016. - №11. - P. 733-736 [Electronic resource]: https://moluch.ru/archive/115/31142/.
14. Zotov, V. B. municipal management System // Textbook for universities (edited by V. B. Zotov). Moscow: publishing house"Municipal Academy"2018.

15. Popadyuk N. whether private property in Russia is Private? (probable scenarios of business development) / / Questions of economy. 2006. no. 1. Pp. 144-157.

16. Natalia Lvovna Krasyukova, Irina Rozhdestvenskaya, Sergey Grigoryevich Eremin, Andrey Ivanovich Galkin, Nail Fedorovich Alyautdinov. Legal regimes of state property management / Utopía y Praxis Latinoamericana, Año: 23, $\mathrm{n}^{\circ}$. 82. Julio-Septiembre, 2018, p. 302-309.

17. Nikita Konstantinovich Popadyuk, Irina Rozhdestvenskaya, Sergey Grigoryevich Eremin, Andrey Ivanovich Galkin, Valery Yevgenyevich Komov. Legal aspects of municipal service in territorial development programs / Utopía y Praxis Latinoamericana, Año: 23, $\mathrm{n}^{\circ}$. 82. Julio-Septiembre, 2018, p. 311-318.

18. Stanislav Prokofiev, Natalia Krasyukova, Eugene Bogatyrev, Alexander Belyaev, Sergey Eremin. Legal aspects of the functioning of the state civil service / Utopía y Praxis Latinoamericana, Año: 23, $\mathrm{n}^{\circ}$. 82. Julio-Septiembre, 2018, p.319-325.

19. Popadyuk, Nikita K. et al. 2018. Features of financial and legal incentives for investment activity in the regions, journal of advanced research in law and Economics, vol. IX, Spring, 1(31): 210 - 218. DOI: 10.14505 / Jarle.B9. 1(31). 26.

20. Prokofiev, Stanislav E. et al. 2018. Professional development of Russian civil servants: legal and organizational aspects, journal of advanced research in law and Economics, vol. IX, Spring, 1(31): $234-241$. DOI: 10.14505 / Jarle.B9. 1(31). 28.

21. Ruchkina, Gulnara et al. 2018. Soft law norms as a new source of financial law in Russia, journal of advanced research in law and Economics, vol. IX, Spring, 1(31): 278 - 286. DOI:10.14505 / Jarle.B9. 1(31). 33.

22. Glebova, I. S., Kotenkova, S. N., \& Abramov, R. A. (2016). The analyses of socio-economic development tendencies of the capital cities in the modern Russia. In Social Sciences and Interdisciplinary Behavior Proceedings of the 4th International Congress on Interdisciplinary Behavior and Social Science, ICIBSOS 2015 (pp. 189-194).

23. Ivanovich, G. V, Aharonovich, A. R., \& Sergeevich, S. M. (2019). Implementation of international experience in support of youth innovative entrepreneurship in the Union state. Academy of Entrepreneurship Journal, 25(Special Issue 1).

24. Ivanisova, N., \& Kurinskaya, L. (2019). Biogeochemical activity of park plants as an indicator of stability of wood plants. World Ecology Journal, 9(1), 40-54. https://doi.org/https://doi.org/10.25726/NM.2019.20.18. 003

25. Gribust, I. (2019). Environmental elements for revitalization of entomophages in the forest plantations of the arid zone. World Ecology Journal, 9(1), 55-69. 
26. https://doi.org/https://doi.org/10.25726/NM.2019.86.67. 004

27. Abramov, R. A., Sokolov, M. S., Surilov, M. N., \& Derevianko, S. V. (2019). Dry mixes for self-leveling floors based on composite binder. Key Engineering Materials, 802, 101-112.

https://doi.org/10.4028/www.scientific.net/KEM.802.101

28. Abramov, R. A., Sokolov, M. S., Surilov, M. N., \& Kochetkov, E. P. (2018). Legal regulation of the synergetic effect of innovation in the structure of national economies of the union state [Regulación jurídica del efecto sinérgico de la innovación en la estructura de las economías nacionales del estado de la unión]. Utopia y Praxis Latinoamericana, 23(82), 281-290. https://doi.org/10.5281/zenodo. 1510262

29. Natalia K. Kondrasheva, Anzhelika M. Eremeeva, Konstantin S. Nelkenbaum, Oleg A. Baulin \& Oleg A. Dubovikov (2019) Development of environmentally friendly diesel fuel, Petroleum Science and Technology, $37: 12,1478-1484$

DOI: 10.1080/10916466.2019.1594285

30. Kondrasheva, N. K., Eremeeva, A. M., \& Nelkenbaum, K. S. (2018). Development of domestic technologies of produsing high quality clean diesel fuel. Izvestiya vysshikh uchebnykh zavedenii khimiya khimicheskaya tekhnologiya, 61(9-10), 76-82.

https://doi.org/10.6060/ivkkt.20186109-10.5651

31. Sudhakar, S., Satheesh, N., Balu, S., Reddy, A. S., \& Murugan, G. (2019). Optimizing joins in a map-reduce for data storage and retrieval performanceanalysis of query processing in HDFS for big data. International Journal of Advanced Trends in Computer Science and Engineering, 8(5), 2062-2067.

https://doi.org/10.30534/ijatcse/2019/33852019

32. Sudharani, K., Sakthivel, N. K., \& Subasree, S. (2019).

B2EIS-RG: Biometric-based bucket encrypting index structure with random generator. International Journal of Advanced Trends in Computer Science and Engineering, 8(2), 165-175.

https://doi.org/10.30534/ijatcse/2019/10822019 